\title{
Ahl al-Kitab perspektif M. Quraish Shihab dan Implikasi Hukumnya dalam Bermuamalah
}

\author{
H. Agus Mukmin., Lc., M. Hum \\ Institut Agama Islam (IAI) Al-Azhaar Lubuklinggau \\ agusmukmin208@gmail.com
}

\begin{abstract}
Pembahasan mengenai Ahl al-Kitab selalu hangat untuk diperbincangkan di semua kalangan, tak terkecuali dalam dunia akademik. Hal ini karena secara tersurat banyak ditemukan di dalam al-Qur;an. Dan ini memberikan pemahaman yang berbeda di kalangan mufasirin terlebih pernyataan al-Qur'an menyebutkan bahwa " mereka semua tidak sama”. Dan pada akhirnya juga berimplikasi pada hukum bertaamul dengan Ahl al-Kitab di masyarakat.

Berdasarkan hal di atas, penulis tertarik untuk melakukan penelitian Ahl al-Kitab perspektif M. Qurais Shihab. Penelitian ini berusaha untuk mengeksploitasi pandangan beliau mengenai Ahl al Kitab. Penelitian ini merupakan penelitian kepustakaan (library research) yang bersifat kualitatif dengan menggunakan metode tafsir maudu'i (tematik) dengan pendekatan historis-sosiologis.

Hasil penelitian ini menyebutkan bahwa pertama, Ahl al-Kitab adalah mereka yang beragama Yahudi dan Nasrani. Kedua, dalam bermuamalah umat Islam dibenarkan untuk menjalin persaudaraan dan kerjasama dengan umat nonMuslim, selama hal itu tidak menyebabkan ekses pencemaran akidah.
\end{abstract}

Kata Kunci: Ahl al-Kitab, pluralitas agama.

\section{PENDAHULUAN}

Eksistensi Ahl al-Kitab telah mendapat pengakuannya di dalam perkembangan khazanah Islam. Hal itu secara tersurat dapat dilihat langsung baik di dalam al-Qur'an maupun Hadits Nabi. ${ }^{1}$ Kata Ahl al-Kitab tersebut di dalam alQur'an sebanyak 31 kali yang tersebar diberbagai surat. ${ }^{2}$ Dari jumlah itu semuanya masuk dalam kategori surat Makkiyah kecuali satu ayat yang tergolong

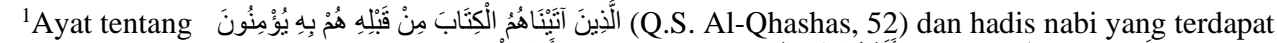

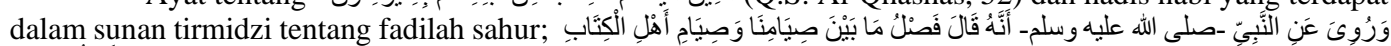
أَكْلَةُ السنَحَرِ

${ }^{2}$ Muhammad Fuad Abdul Baqi, Mujam Mufahros Al Fadhil Quran Al Ahdzim, (Kairo, DarAl Kutub Misriyyah: 1942) h. 96 
Madaniyah. ${ }^{3}$ Sebagaimana dipahami bahwa pengklasifikasian ayat atau surat menjadi Makkiyah dan Madaniyah adalah salah satu cara para Mufassir memberikan tafsirannya terhadap suatu ayat al-Qur'an.

Ahl al-Kitab merupakan salah satu term di dalam al-Qur'an yang masih mendapat perhatian banyak bagi pengkaji Islam. Hal itu disebabkan mereka tidak sepakat dalam memahami maknanya. Akibatnya, dari tiap pakar akan memberikan implikasi hukum yang berbeda di tatanan kehidupan sosial masyarakat. Seperti, hukum mengkonsumsi dari sesembelihan Ahl al-Kitab, jual beli hingga memilih pemimpin dari golongan Ahl al-Kitab. Kenyataan ini dipertegas dengan satu ayat di dalam al-Qur'an yang menyebutkan bahwa Ahl al-Kitab tidak semua sama. ${ }^{4}$

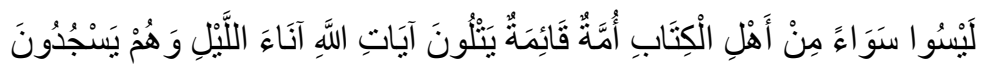

Artinya: "Mereka itu tidak (seluruhnya) sama. Di antara Ahli Kitab ada golongan yang jujur, mereka membaca ayat-ayat Allah pada malam hari, dan mereka (juga) bersujud (salat)"'.

Diantara para ahli yang mencoba menawarkan pemahaman atas Ahl al-Kitab adalah Prof. Dr. Quraish Shihab, MA. Ada beberapa alasan terkait signifikannya beliau dalam peelitian ini yaitu, Pertama, Quraish Shihab yang dikenal sebagai master tafsir di Indonesia ${ }^{5}$ dan menjadi salah seorang penafsir al-Qur'an Indonesia yang relatif memiliki pendidikan terbaik di antara para penafsir al-Qur'an di Indonesia lainnya sehingga karyanya merupakan standar baru bagi studi al-Qur'an yang digunakan di Indonesia. ${ }^{6}$ Disamping itu, ia dikenal tidak hanya menguasai ilmu dirayah tapi juga riwayah al-Qur'an. ${ }^{7}$ Kedua, pergulatannya dengan tradisi Arab dimana teks al-Qur'an dimunculkan dalam bahasa itu, dan konteks Indonesia dimana ia hidup dan berkarya, telah memperkaya dan mewarnai corak dan warna penafsiran yang dibangunnya. Ketiga, dalam konteks Indonesia, karya-karya

\footnotetext{
2016. H. 21

${ }^{3}$,Muhammad Ghalib. Ahl al-Kitab Makna dan Cakupannya dalam al-Q "Yogyakarta: IRCiSoD, ${ }^{4}$ Qs. Ali Imran (3):113 2003), 180.

${ }^{5}$ Islah Gusmian, Khazanah Tafsir Indonesia Dari Hermeneutika Hingga Ideologi (Jakarta: Teraju,

${ }^{6}$ Howard M. Federspiel, Kajian Al-Qur'an di Indonesia Dari Mahmud Yunus Hingga Quraish Shihab, terj. Tadjul Arifin (Bandung: Mizan, 1996), 295.

${ }^{7}$ Ilmu dirayah dalam konteks al-Qur'an terkait dengan teori tentang al-Qur'an termasuk ilmu tafsir, sedangkan ilmu riwayahnya adalah ilmu tentang produk tafsir-tafsir itu sendiri baik yang berdasar riwayat dari Nabi maupun generasi setelahnya atau berdasar rasio.
} 
Quraish Shihab yang ditulis tidak hanya bagi kalangan terpelajar namun juga masyarakat awam itu, ${ }^{8}$ diasumsikan menjadi referensi yang berpengaruh dalam masyarakat.

Dengan demikian, kajian atas karya tersebut akan bermanfaat untuk menilai sejauh mana karya tersebut dapat dipertimbangkan sebagai rujukan studi tentang Islam atau ada pertimbangan lain sehingga karya itu memiliki kelebihan dan kekurangan tertentu.

\section{A. PENGERTIAN AHL AL-KITAB}

Ahl al-Kitab secara etimologi berasal dari dua suku kata yaitu kata Ahli yang merupakan serapan dari bahasa Arab dan kitab. Kata ahl adalah bentuk kata benda (isim) dari kata kerja (Fi'il) yaitu kata ahila-ya'halu-ahlan. Al-Ahl yang bermakna juga famili, keluarga, kerabat. Ahl ar-rajul artinya adalah istrinya, ahl addâr artinya penduduk kampung, ahl al-'amr artinya penguasa, ahl almadzhab artinya orang-orang yang beragama dengan mazhab tersebut, ahl alwabar artinya penghuni kemah (pengembara), ahl al-madaratau ahl alhadhar artinya orang yang sudah tinggal menetap. ${ }^{9}$ Kata $a h l$ telah disebutkan sebanyak 125 kali di dalam Al-Qur'an. Kata tersebut, ditemukan penggunaannya secara bervariasi. Tetapi secara umum, makna yang dikandungnya dapat dikembalikan kepada pengertian kebahasaan. Misalnya, menunjuk kepada suatu kelompok tertentu, seperti ahl al-bayt (Qs. 33:33) yang ditujukan kepada keluarganya Nabi Muhammad saw.

Sedangkan kata Al-Kitab tersebut di dalam al-Qur'an setidaknya 319 kali yang terdiri dari perbedaan variasi, meliputi pengertian tulisan, kitab, ketentuan dan kewajiban. Term al-Kitab yang menunjuk kepada kitab suci yang diturunkan Allah kepada Rasul-Nya, penggunaannya bersifat umum, dalam arti, meliputi semua kitab suci yang telah diturunkan oleh Allah, baik kitab suci yang telah diturunkan kepada Nabi dan rasul sebelum Nabi Muhammad saw, seperti Nabi Musa dan Nabi Isa. ${ }^{10}$

Dari pengertian di atas, kata $a h l$ jika disambung dengan al-kitâb, tampaknya yang paling sesuai pengertiannya secara bahasa, adalah orang-orang yang beragama

${ }^{8}$ Federspiel, Kajian Al-Qur'an, 297-298.

${ }^{9}$ Ibnu Al-Mandzur, Lisaan Al-Arab

${ }^{10}$ Muhammad Galib M, Ahl Al-Kitab, (Yogyakarta: Ircisod, 2016), hlm. 39-43 
sesuai dengan al-Kitab. Dengan ungkapan lain, mereka adalah para penganut atau pengikut al-Kitab. Dalam Kamus Besar Bahasa Indonesia disebutkan bahwa ahlul kitab adalah ahli yaitu orang-orang yang berpegang kepada kitab suci selain alQur'an. ${ }^{11}$

Sedangkan Ahl al-Kitab menurut terminology adalah "Pemilik Kitab Suci", yakni para umat nabi yang diturunkan kepada mereka kitab suci (wahyu Allah)". ${ }^{12}$ Di antara mereka adalah Kaum Yahudi dan Nasrani. Dinamakan ahlu kitab karena telah diberikan kepada mereka kitab suci oleh Allah swt.

Dari pengertian secara etimologi maupun terminology dapat dipahami bahwa Ahl al-Kitab adalah kaum Yahudi dan Nasrani. Hal ini sebagaimana disebutkan oleh Imam al Baidhawi ketika menafsirkan Surat Al-Maidah : 5, beliau mengatakan bahwa ahli kitab mencakup orang-orang yang diberikan kepada mereka al Kitab yaitu orang-orang Yahudi dan Nasrani. ${ }^{13}$

Imam al-Syafi'i memberikan definisi yang lebih sempit lagi yaitu bahwa yang termasuk Ahli Kitab hanyalah pengikut Yahudi dan Nasrani dari Bani Israil saja. ${ }^{14}$ Ini berarti siapa saja yang mauk ke dalam agama Yahudi dan Nasrani yang berasal dari Bani Israil maka tidak bisa disebut sebagai Ahl al-Kitab.

\section{B. M. QURAISH SHIHAB : BIOGRAFI SINGKAT}

Quraish Shihab lahir di Rappang, Sulawesi Selatan, pada 16 Pebruari 1944. Pendidikan dasarnya diselesaikan di Ujungpandang, kemudian pendidikan menengah diselesaikan di Malang sambil "nyantri” di Pondok Pesantren Darul Hadis al- Faqihiyyah. ${ }^{15}$ Ia berasal dari keturunan Arab yang terpelajar. Ayahnya, Abdurrahman Syihab (1905-1986) adalah lulusan Jami'atul Khair Jakarta, sebuah lembaga pendidikan Islam tertua di Indonesia yang mengedepankan gagasangagasan Islam modern. Ayahnya ini, selain seorang guru besar dalam bidang tafsir,

\footnotetext{
${ }^{11}$ Kamus Besar bahasa Indonesia, kata Ahlul Kitab

12 Imam Syafi'i, Arisalah

${ }^{13}$ Tafsir al Baidhawi juz II hal 48

${ }^{14}$ Muhammad ibn Idris al-Syafi'i, Al-Umm, jil. 6, diedit oleh Rif'at Fauzi 'Abd al-Mathlab, (T.Tmpt : Dar al-Wafa', cet. I, 2001 1992), 6.

${ }^{15}$ Lihat, "Tentang Penulis" dalam M. Quraish Shihab, Membumikan al-Qur'an (Bandung: Mizan,
} 
juga pernah menduduki jabatan Rektor IAIN Alauddin, dan tercatat sebagai salah seorang pendiri Universitas Muslim Indonesia (UMI) di Ujungpandang. ${ }^{16}$

Pada tahun 1958, ia berangkat ke Kairo, Mesir atas bantuan beasiswa dari Pemerintah daerah Sulawesi. Setelah sembilan tahun mengikuti pendidikan mulai Tsanawiyah hingga kuliah S1, akhirnya Quraish Shihab pada tahun 1967 memperoleh gelar LC dalam jurusan tafsir dan hadis di Universitas al-Azhar, Kairo. Selanjutnya ia mengambil S 2 di jurusan yang sama dan dua tahun kemudian memperoleh gelar MA dalam bidang tafsir al-Qur'an dengan tesis Al-I'jaz alTasyri'iy li al-Qur'an al-Karim. ${ }^{17}$

Setelah pulang beberapa tahun ke Indonesia dan menduduki beberapa jabatan di Ujung Pandang, pada tahun 1980, Quraish Shihab kembali ke Mesir untuk mengambil S 3 di universitas yang sama. Dua tahun kemudian, dengan disertasi berjudul Nazm ad-Durar li al-Biqa'iy Tahqiq wa Dirasah, ia berhasil memperoleh glar doktor dalam ilmu al-Qur'an dengan yudisium Summa Cum Laude disertai dengan penghargaan tingkat I. Ia menjadi orang Asia Tenggara pertama yang memperoleh gelar doktor dalam ilmu al-Qur'an dari Universitas tersebut. ${ }^{18}$

Setelah kembali ke Indonesia, ia ditempatkan di Fakultas Ushuluddin dan Pascasarjana IAIN Syarif Hidayatullah Jakarta. Selain itu ia menjabat Ketua Majelis Ulama Indonesia Pusat (sejak 1984), Anggaota Lajnah Pentashih al-Qur'an Departemen Agama (sejak 1989), Anggota Badan Pertimbangan Pendidikan Nasional (sejak 1989), pengurus Perhimpunan Ilmu-Ilmu Syari'ah, pengurus Konsorsium Ilmu-Ilmu Agama Departemen Pendidikan dan Kebudayaan dan asisten Ketua Umum ICMI, Rektor IAIN Syarif Hidayatullah, Menteri Agama Kabinet Pembangunan VII tahun 1998 hingga pemerintahan kabinet ini tumbang oleh gerakan reformasi tahun 1998 serta jabatan lainnya. ${ }^{19}$

Sebagian karya yang telah dihasilkannya ialah: Tafsir al-Manar, keistimewaan dan Kelemahannya (Ujungpandang: IAIN Alauddin, 1984), Mahkota

\footnotetext{
${ }^{16}$ Lihat Arief Subhan, "Menyatukan Kembali Al-Qur'an dan Ummat, Menguak Pemikiran M. Quraish Shihab Shihab", dalam Jurnal Ilmu dan Kebudayaan Ulumul Qur'an, No. 5, Vol. IV Th. 1993, 10.

17“"Tentang Penulis” dalam Quraish Shihab, Membumikan Al-Qur'an, hlm. 6; Islah, Khazanah Tafsir Indonesia, 80.

${ }^{18}$ Islah, Khazanah Tafsir Indonesia, 81.

${ }^{19}$ Islah, Khazanah Tafsir Indonesia, 81.
} 
Tuntunan Ilahi (Tafsir Surat al-Fatihah) (Jakarta: Untagma, 1988), Membumikan Al-Qur'an, Fungsi dan Peran Wahyu dalam Kehidupan Masyarakat (Bandung: Mizan, 1992), Lentera Hati Kisah dan Hikmah Kehidupan (Bandung: Mizan, 1994), Wawasan al-Qur'an (Bandung: Mizan, 1996), Hidangan Ilahi Ayat-ayat Tahlil (Jakarta: Lentera Hati, 1997), Tafsir al-Misbah, Pesan, Kesan dan Keserasian al-Qur'an (Jakarta: Lentera Hati, 2000) dan beberapa buku yang lain. ${ }^{20}$

\section{AYAT-AYAT TENTANG AHL AL-KITAB}

Sebagaimana tersebut di atas bahwa ayat al-Qur'an yang berbicara mengenai Ahl al-Kitab diulang sebanyak 31 kali. Berikut diantara ayat-ayat tersebut adalah;

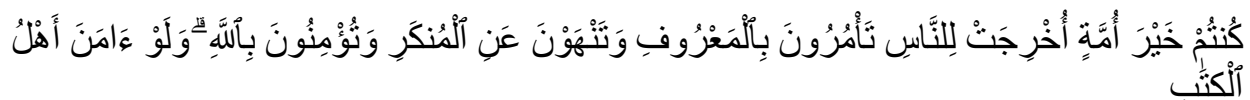

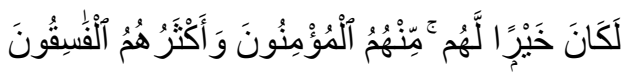

'Kamu (umat Islam) adalah umat terbaik yang dilahirkan untuk manusia, (karena kamu) menyuruh (berbuat) yang ma'ruf, dan mencegah kemungkaran, dan beriman kepada Allah. Apabila para Ahli Kitab beriman, maka itu akan lebih baik bagi mereka. Beberapa dari mereka ada yang beriman ... '(Q.S. Al 'Imran, 110)

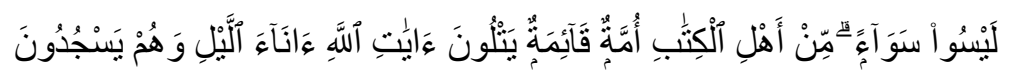

'Mereka itu tidak (semuanya) sama. Ada di antara Ahli Kitab yang jujur, mereka membaca ayat-ayat Allah pada malam hari, dan mereka (juga) bersujud (sholat).'(Q.S. Al 'Imran, 113)

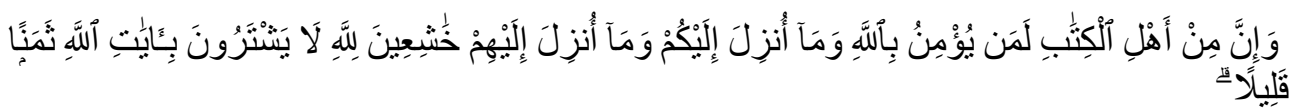

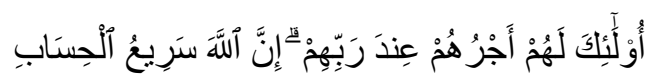

'Dan sesungguhnya di antara Ahli Kitab ada yang beriman kepada Allah dan kepada apa yang telah diturunkan kepadamu dan yang diturunkan kepada mereka, karena mereka orang - orang yang berendah hati kepada Allah, dan mereka tidak memperjualbelikan ayat-ayat Allah dengan harga yang murah. Mereka mendapatkan pahala di sisi Tuhan mereka. Sungguh Allah sangat cepat perhitungannya-Nya.' (Q.S. Al Imran, 199)

${ }^{20}$ Islah, Khazanah Tafsir Indonesia, 82. 


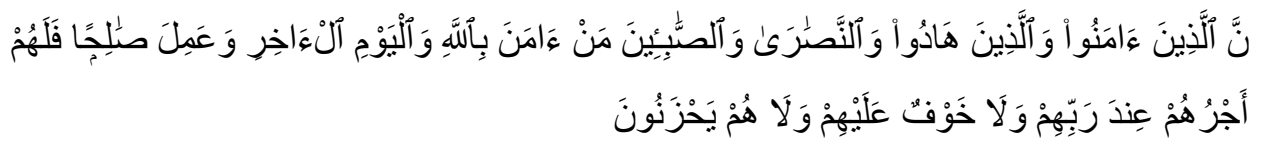

'Sesungguhnya orang-orang yang beriman, orang-orang Yahudi, orangorang Nasrani, dan orang-orang Sabiin, siapa saja (di antara mereka) yang beriman kepada Allah dan hari akhir dan melakukan kebajikan, akan ada pahala bagi mereka di sisi Tuhan mereka, tidak ada rasa takut pada mereka, dan mereka tidak bersedih hati.'(Q.S. Al-Baqarah, 62)

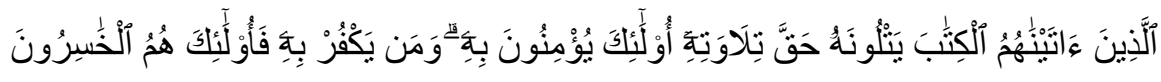

'Orang-orang yang telah Kami berikan Kitab, mereka membacanya sebagaimana mestinya, mereka itulah yang beriman kepadanya.' (Q.S. AlBaqarah, 121)

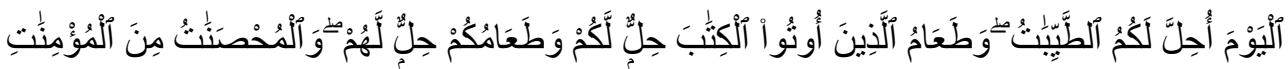

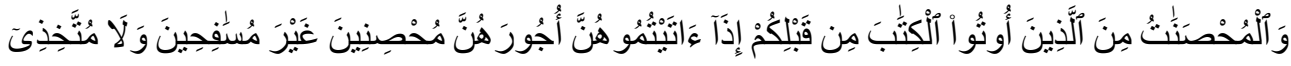

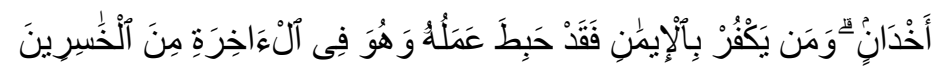

'Pada hari ini dihalalkan bagimu segala yang baik-baik. Makanlah (sembelihan) Ahli Kitab itu halal bagi kamu dan makananmu juga halal bagi mereka. Dan (dihalalkan bagimu menikahi) perempuan - perempuan yang menjaga kehormatan di antara perempuan - perempuan yang beriman dan perempuan - perempan yang menjaga kehormatan di antara orang yang diberi kitab sebelum kamu, apabila kamu membayar maskawin mereka untuk menikahinya, tidak dengan maksud berzina dan bukan untuk menjadikan perempuan piaraan. Barangsiapa kafir setelah beriman maka sungguh, sia - sia amal mereka dan di akhirat dia termasuk orang - orang yang rugi.' Q.S. AlMaidah : 5

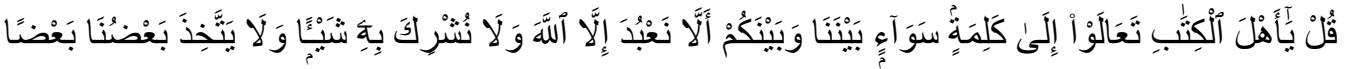

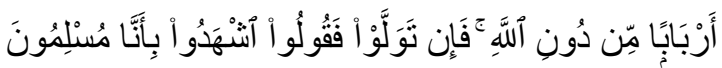

'Katakanlah: "Hai Ahli Kitab, marilah (berpegang) kepada suatu kalimat (ketetapan) yang tidak ada perselisihan antara kami dan kamu, bahwa tidak kita sembah kecuali Allah dan tidak kita persekutukan Dia dengan sesuatupun dan tidak (pula) sebagian kita menjadikan sebagian yang lain sebagai Tuhan selain Allah." Jika mereka berpaling maka katakanlah kepada mereka: "Saksikanlah, bahwa kami adalah orang-orang yang berserah diri (kepada Allah)". ' Q.S. Al Imran : 64 


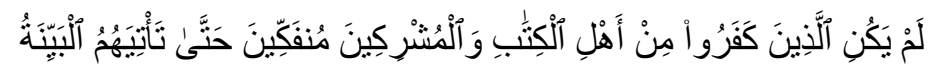

"Orang-orang kafir yakni ahli kitab dan orang-orang musyrik (mengatakan bahwa mereka) tidak akan meninggalkan (agamanya) sebelum datang kepada mereka bukti yang nyata, QS Al-Bayyinah : 1".

\section{AHL AL-KITAB PERSPEKTIF M. QURAISH SHIHAB}

Dalam menjelaskan satu tema M. Quraish Shihab tidak hanya mengambil ayat-ayat al-Qur'an tentang tema itu saja, akan tetapi beliau juga mengambil termterm ayat yang berhubungan dengan tema tersebut secara menyeluruh. Karena mengambil satu dua ayat untuk berbicara tentang tema tertentu, maka dimungkinkan akan menghasilkan kesimpulan yang kurang baik bahkan keliru. Oleh sebabnya, dalam menafsirkan ayat-ayat al-Qur'an tentang tema tertentu beliau selalu melibatkan konteks (munasabah) ayat, sejarah, asbab an-nuzul, penjelasan Nabi (sunnah), dan sebagainya. Dan untuk melengkapi kekurangan yang ada, membandingkan dengan pendapat ahli, menurutnya, juga diperlukan. ${ }^{21}$

Hal demikian juga berlaku ketika beliau membahas tentang Ahl al-Kitab. M. Quraish Shibab tidak cukup hanya dengan mengambil beberapa ayat tentang $A h l$ al-Kitab kemudian membuat kesimpulan. Namun beliau juga mengambil term, istilah atau hal-hal yang berkaitan dengan Ahl al-Kitab yang termuat di dalam alQur'an seperti, istilah ahl al-Kitab, al-Qur'an juga menggunakan istilah utu alKitab (18 kali), utunasiban min al-Kitab (tiga kali), al-Yahud (delapan kali), alLazina hadu (sepuluh kali), Bani Israil (empat puluh satu kali), an-Nasara (empat belas kali) dan istilah lainnya. ${ }^{22}$

Selanjutnya menurut M. Quraish Shihab, jika al-Qur'an menggunakan kata al-Yahud, maka isinya adalah kecaman atau gambaran negatif tentang mereka. ${ }^{23}$ Seperti; Ia mengambil contoh firman Allah tentang kebencian Yahudi terhadap umat Muslim (Q.S. al-Maidah [5]: 82),

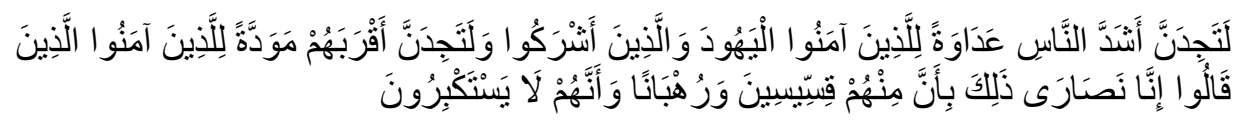

\footnotetext{
${ }^{21}$ Quraish Shihab, “Ahl Al-Kitab” dalam Wawasan Al-Qur'an, 347.

${ }^{22}$ Quraish Shihab, "Ahl al-Kitab, 348.

${ }^{23}$ Quraish Shihab, "Ahl al-Kitab”, 348.
} 
Ketidakrelaan umat Yahudi dan Nashrani terhadap umat Muslim hingga mereka mengikuti agama mereka (Q.S. al-Baqarah [2]: 120);

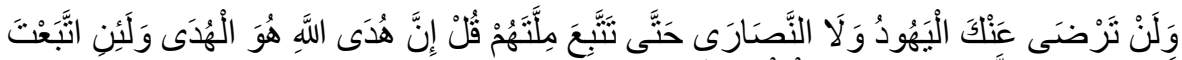

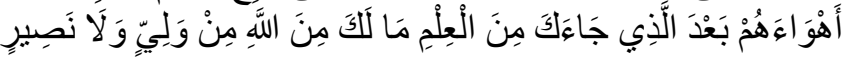

atau pengakuan orang Yahudi dan Nashrani bahwa mereka adalah anakanak dan kekasih Allah (Q.S. al-Maidah [5]: 18),

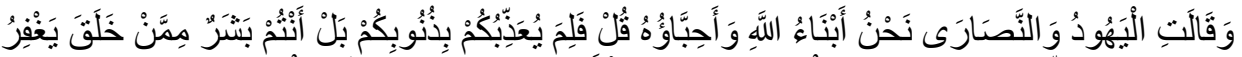

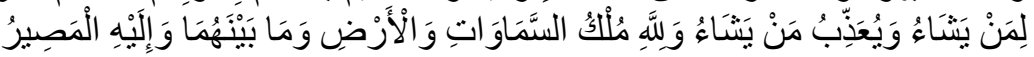

atau pernyataan orang Yahudi bahwa Allah itu kikir (Q.S. al-Maidah [5]: 65) dan Demikian juga petunjuk makna yang lahir dari penggunaan kata al-Lazina hadu. ${ }^{24}$ Jika digunakan, kata ini menunjukan beberapa arti: kecaman, seperti terhadap mereka yang merubah kalimah Tuhan (Q.S. an-Nisa` [4]: 46),

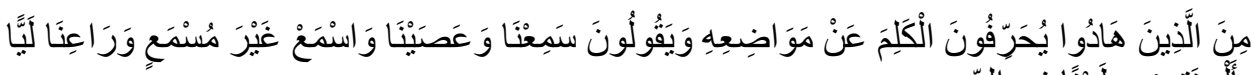

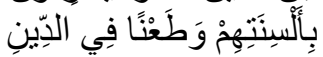

atau bahwa mereka rajin mendengarkan berita tentang umat Islam untuk menyebar luaskan kebohongan. (Q.S. al-Maidah [5]: 41). Ada juga yang bersifat netral, seperti janji kepada mereka yang beriman dan beramal baik agar tidak merasa takut atau sedih (Q.S. al-Baqarah [2]: 62)

Kata an-Nasara seperti halnya kata al-Lazina hadu, terkadang digunakan dalam konteks positif dan pujian seperti; dalam Q.S. al-Maidah [5]: 82 tentang persahabatan mereka yang akrab dengan umat Islam,

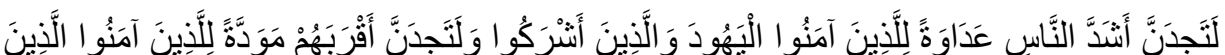

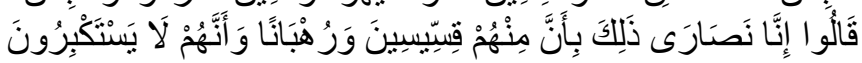

Artinya: "Pasti akan kamu dapati orang yang paling keras permusuhannya terhadap orang-orang yang beriman, yaitu orang-orang Yahudi dan orang-orang musyrik. Dan pasti akan kamu dapati orang yang paling dekat persahabatannya dengan orang-orang yang beriman ialah orang-orang yang berkata, "Sesungguhnya kami adalah orang Nasrani." Yang demikian itu karena di antara mereka terdapat para pendeta dan para rahib, (juga) karena mereka tidak menyombongkan diri"

dan terkadang merujuk ke dalam konteks kecaman, seperti dalam Q.S. alBaqarah [2]: 120 yang berbicara tentang ketidakrelaan mereka hingga umat Muslim mengikuti agama mereka

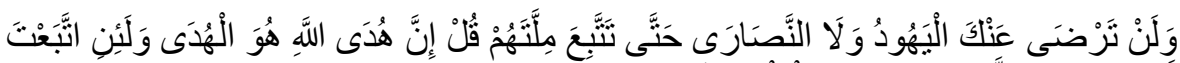

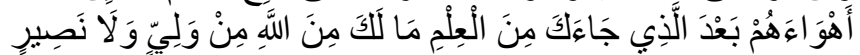

${ }^{24}$ Quraish Shihab, “Ahl al-Kitab”, 348. 
Artinya: Dan orang-orang Yahudi dan Nasrani tidak akan rela kepadamu (Muhammad) sebelum engkau mengikuti agama mereka. Katakanlah, "Sesungguhnya petunjuk Allah itulah petunjuk (yang sebenarnya)." Dan jika engkau mengikuti keinginan mereka setelah ilmu (kebenaran) sampai kepadamu, tidak akan ada bagimu pelindung dan penolong dari Allah.

Dan terkadang dalam konteks yang netral, bukan cercaan dan bukan pujian seperti dalam Q.S. al-Hajj [22]: 17 yang berisi putusan keadilan Tuhan yang akan diberikan kepada kelompok-kelompok yang ada di Hari Kiamat. ${ }^{25}$

Dalam menilai Ahl al-Kitab, Quraish Shihab mencoba melihat berbagai ayat yang terkait. Di dalamnya ia menemukan redaksi al-Qur'an yang bervariatif untuk menunjukkan keyakinan dan sekte yang beraneka ragam. Kebanyakan berisi kecaman meski sesekali bersikap memuji. ${ }^{26}$ Secara umum bisa dikatakan bahwa umat Nashrani lebih bersahabat dibandingkan umat Yahudi yang menunjukkan sikap yang kurang baik terhadap umat Islam. ${ }^{27}$ Untuk umat Yahudi, Quraish Shihab melihat kecaman tersebut disebabkan oleh sikap politik dan ekonomi mereka.

Selain hal di atas, M. Quraish Shihab ketika menjelaskan Ahl al-Kitab juga tidak melepaskannya dengan pluralitas agama dan ini tentunya berimplikasi pada hukum sosial kemasyarakatan. Karenanya ia menegaskan bahwa al-Qur'an tidak menjadikan perbedaan agama sebagai alasan untuk tidak menjalin kerjasama, lebihlebih mengambil sikap tidak bersahabat. Bahkan al-Qur'an, menurutnya dengan mengutip pendapat Ibn 'Arabi, sama sekali tidak melarang umat Islam untuk memberikan sebagian hartanya kepada siapapun selama mereka tidak memerangi kaum Muslim dengan motivasi keagamaan atau mengusir kaum Muslimin dari tanah kelahiran mereka. ${ }^{28}$ Demikian juga larangan mengangkat mereka menjadi wali dalam al-Qur'an tidaklah bersifat mutlak. ${ }^{29}$

Pluralitas dalam berbagai bentuknya, menurut Quraish Shihab, adalah kebijaksanaan Allah. Ketika menafsirkan Q.S. an-Nahl [16]: 93 "bahwa seandainya Allah menghendaki, tentu Ia akan menjadikan kamu umat yang satu", Quraish Shihab menyatakan,

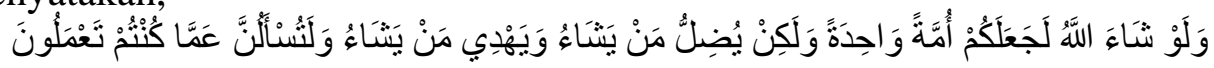

${ }^{25}$ Quraish Shihab, "Ahl al-Kitab”, 348-349.

${ }^{26}$ Quraish Shihab, "Ahl al-Kitab", 351-355.

${ }^{27}$ Quraish Shihab, "Ahl al-Kitab”, 361-362, 371.

${ }^{28}$ Quraish Shihab, "Ahl al-Kitab”, 365.

${ }^{29}$ M. Quraish Shihab, Tafsir al-Misbbah Pesan Kesan dan Keserasian al-Qur'an, Vol. III (Jakarta: Lentera Hati, 2005), 116-117. 
"Tetapi Allah tidak menghendaki yang demikian. Karena itu Ia memberikan kebebasan kepada manusia untuk memilih sendiri jalan yang dianggapnya baik, mengemukakan pendapatnya secara jelas dan bertanggung jawab. Di sini dapat ditarik kesimpulan bahwa kebebasan berpendapat, termasuk kebebasan memeilih agama, adalah hak yang dianugerahkan Allah kepada setiap insan." 30

Menurutnya, prinsip toleransi yang baik adalah prinsip resiprositas, hubungan timbal balik dan damai antara pemeluk agama yang berbeda. ${ }^{31}$ Ini yang dalam bahasa kontemporer disebut dengan toleransi pasif. Maka dialog diperlukan dimana umat Islam "tidak dianjurkan" melakukan truth claim kepada mitra dialog. ${ }^{32}$

Selanjutnya beliau juga menjelaskan terkait tentang toleransi bahwa umat Islam dibenarkan untuk menjalin persaudaraan dan kerjasama dengan umat nonMuslim, selama hal itu tidak menyebabkan ekses pencemaran akidah. ${ }^{33}$ Makanya, dalam konteks mengucapkan "Selamat Natal”, Quraish Shihab menganggapnya sebagai hal yang mubah selama tidak menimbulkan ekses pencemaran akidah dan selama tidak menimbulkan keraguan akidah di kalangan umat Islam yang lain. ${ }^{34}$ Sementara itu, menurutnya, mengerjakan shalat di Gereja adalah dilarang karena adanya lambang-lambang yang menunjukkan kepercayaan yang berbeda dengan akidah Islam. ${ }^{35}$ Quraish Shihab tidak menjelaskan bagaimana hal-hal itu dianggap mencemarkan akidah, menimbulkan keraguan atau tidak. Demikian pula pandangannya yang dapat dianggap liberal adalah tentang kebolehan memilih pemimpin dari kalangan non-Muslim asalkan bisa membawa kebaikan bagi semua pihak. Ini antara lain dibuktikan oleh sikap Umar yang memberikan jabatan penting tertentu kepada seorang non-Muslim yang dianggap layak. ${ }^{36}$ Dalam hal seperti ini, yang sangat nampak dari pertimbangannya adalah unsur manfaat dan madharat yang mungkin timbul dari pilihan yang ditawarkan.

Dengan pemikirannya seperti ini, maka tampak bahwa beliau berfikir romantik. Dengan mengikuti redaksi al-Qur'an tertentu yang berisi kecaman

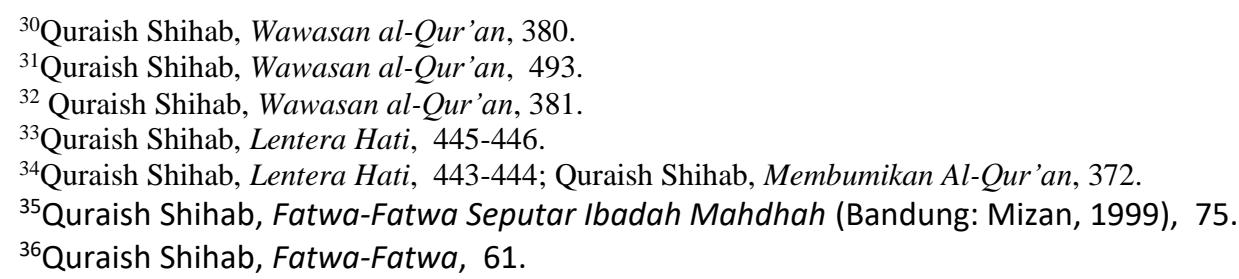


terhadap mereka, terkadang ia memahaminya dalam konteks Ahl al-Kitab saat itu yang ditemui al-Qur'an. Karena itu, menurutnya, beberapa ayat yang beredaksi kecaman bisa dipahami dalam konteks permusuhan ekonomi dan politik saat alQur'an turun dan bukan karena masalah agama. Ketika menjelaskan makna ayat alMagdubi alaihim dan al-Dallin, ia juga tampak sangat tergantung terhadap hadis Nabi, yang memang mengatakan demikian, ${ }^{37}$ tanpa mencoba memberi solusi dengan mengkaji Kristen sekarang dan variasi dan dinamika umat Kristiani dalam memahami agamanya dulu dan sekarang.

Dan juga beliau tidak membandingkan dan mengelompokan Ayat-ayat di alQur'an lain yang bernada netral, misalnya, untuk menjadi entry point bagi konstruksi dialog teologis dan hubungan umat Islam dan Kristen yang lebih baik di masa sekarang. Dari biografi yang ada, tampak bahwa Quraish Shihab tidak cukup familiar dengan data-data tentang ajaran Kristen yang memang tidak monolitik. Hal ini penting untuk memposisikan agama Kristen sebagai mitra dialog Islam secara intelektual. Namun bisa juga sikap diam ini disebabkan oleh keyakinan Quraish Shihab akan kebenaran al-Qur'an (Qur'an minded) karena menurutnya, redaksinya yang sangat teliti itu. Dalam hal ini, nampak Quraish Shihab kurang mendialektikkan informasi al-Qur'an dalam konteks kebutuhan masyarakat Indonesia. Sejauh dijadikan argumen tambahan, maka terdapat alasan lain, yaitu posisi Quraish Sihab sebagai public figure menyulitkannya untuk membicarakan sesuatu yang mungkin tidak mudah diterima kaum Muslim awam terutama tentang dimungkinkannya kebenaran dalam agama lain.

\section{KESIMPULAN}

Dari penelitian di atas, ada beberapa kesimpulan diantaranya adalah, pertama, bahwa dalam memahami suatu ayat beliau tidak secara tekstualis atau dalamhal ini ia juga memerlukan Munasabah dan Asbab an-Nuzul suatu ayat. Artinya ia sangat kontekstualis dengan selalu merujuk kepada konteks Arab yang melahirkan teks, atau ia mengkonstruksi nilai secara umum, tapi belum memberikan ruang dialektik yang luas dan utuh kepada realitas sosial dimana penafsir berada.

\footnotetext{
${ }^{37}$ Shihab, Tafsir al-Misbah, Vol. 1, 74-77.
} 
Kedua, dalam menafsirkan suatu ayat secara Maudhu'i beliau tidak hanya mengambil satu atau dua ayat saja dalam hal ini tentang Ahl al-Kitab saja, akan tetapi beliau juga mengambil beberapa ayat di dalam al-Qur'an atau Hadits Nabi yang semakna dengan tema Ahl al-Kitab.

Ketiga, kontribusinya dalam tafsir al-Qur'an sangatlah besar dan layak dihargai. Dimana hasil tafsirannya yang kontemporer tentunya sangat relevan dengan perkembangan zaman atau lebih dikenal dengan istilah al-Qur'an solihunlikulli zaman wal makan.

\section{DAFTAR PUSTAKA}

Abidin, Ahmad Zainal, “The Qur'an and Religious Pluralism: Fazlur Rahman's Perspective", Tesis MA, CRCS UGM Yogyakarta, 2004.

Abu Zayd, Nasr Hamid. Mafhu>m an-Nas\}s\}: Dira $>$ sat fi 'Ulu>m al-Qur'a $>n$. Kairo: al-Hai`ah al-Mishriyah al-`Ammah li al-Kitab, 1993.

-----. Rethingking the Qur'an: Toward a Humanistic Hermeneutics. Amsterdam : SWP Publishers, 2004.

Achmad, Nur. Pluralitas Agama: Kerukunan dalam Keragaman. Jakarta: Kompas, 2001.

Bahtiar, Edi. "Mencari Format Baru Penafsiran Al-Qur'an di Indonesia (Telaah terhadap Pemikiran M. Quraish Shihab)", Tesis S 2, Pascasarjana IAIN Sunan Kalijaga Yogyakarta, 1999.

Bertens, K. Filsafat Barat Abad XX, jld. I. Jakarta: Gramedia, 1996.

El Fadl, Khaled Abou. Speaking in God's Name Islamic Law, Authority,, and Women. Oxford: Oneworld, 2001.

Eriyanto. Analisis Wacana, Pengantar Analisis Teks Media.Yogyakarta: LkiS, 2001.

Esack, Farid. Qur'an, Liberation and Pluralism An Islamic Perspective of Interreligious Solidarity against Oppression. Oxford: Oneworld Publication, 1997.

Federspiel, Howard M. Kajian Al-Qur'an di Indonesia Dari Mahmud Yunus Hingga Quraish Shihab, terj. Tadjul Arifin. Bandung: Mizan, 1996.

Gusmian, Islah. Khazanah Tafsir Indonesia Dari Hermeneutika Hingga Ideologi. Jakarta: Teraju, 2003. 
Haddad, Ivonne Y. "Islamist Depiction of Christianity in the Twentieth Century: the Pluralism debate and the Depiction of the Other", Islam and ChristianMuslim Relations, Vol. 7, No. 1, 1996.

Hanafi, Hassan. “Apa Arti Kiri Islam”, dalam Kazuo Shimogaki, Kiri Islam Antara Modernisme dan Postmodernisme Telaah Kritis Pemikiran Hassan Hanafi, (terj) M. Imam Aziz dan M. Jadul Maula. Yogyakarta: LkiS, 1994.

----. Dialog Agama dan Revolusi, terj. Tim Pustaka Firdaus. Jakarta: Pustaka Firdaus, 1991.

-----. Dira $>$ sa $>$ t Falsafiyah. Kairo: Maktabah Anglo-Misriyah, 1988.

----. Dira $>$ sa $>t$ Isla $>$ miyyah. Kairo: Maktabah Anglo-Misriyah, 1981.

-----. At-Tura $>s \backslash$ wa al-Tajdi $>d$ Mauqifuna min al-Turas $\backslash$ al-Qadi $>m$. Kairo: alMarkaz al-Arabi li al-Bahs wa an-Nasyr, 1980.

-----. Islam in The Modern World: Tradition, Revolution and Culture, vol. 2. Kairo: Anglo-Egyptian Bookshop, 1995.

Hick, John, "Religious Pluralism" dalam Michel Peterson et.all, Philosophy of Religion: Selected Readings. New York and Oxford: Oxford University Press, 1996.

-----. An Interpratation of Religion, Human Responses to Transcendent. New Haven and London: Yale University Press, 1989.

Ikhwan, M. Nur. "Hermenutika al-Qur'an Analisis Peta Perkembangan Metodologi Tafsir al-Qur'an Kontemporer," Skripsi, Jurusan Tafsir Hadis, Fakultas Ushuludin IAIN Sunan Kalijaga Yogyakarta, 1996.

Mouw, Richard J. and Sander Griffioen, Pluralism and Horizon. USA: Wm.B.Berdmans Publishing Co., 1993.

Neufeldt, Victoria. Webster's New World College Dictionary. New York: Macmillan, 1995.

Orsbone, Grant R., The Hermeneutical Spiral. Illinois: Intervarsity Press, 1991.

Rahman, Fazlur. Major Themes of the Qur'an. Minneapolis and Chicago: Bibliotheca Islamika, 1980.

-----. Islam and Modernity: Transformation of an Intellectual Tradition (Chicago: The University of Chicago Press, 1982)

Safi, Omid (ed.), Progressive Muslims on Justice, Gender, and Pluralisme. Oxford: Oneworld, 2003.

Shihab, M.Quraish. Fatwa-Fatwa Seputar Ibadah Mahdhah. Bandung: Mizan, 1999.

-----. Lentera Hati Kisah dan Hikmah Kehidupan. Bandung: Mizan, 1999.

-----. Membumikan al-Qur'an. Bandung: Mizan, 1992. 
-----.Tafsir al-Misbbah Pesan, Kesan dan Keserasian Al-Qur'an. Vol. I-III Jakarta: Lentera Hati, 2000, 2005.

-----Tafsir Al-Qur'an al-Karim Tafsir Atas Surat-Surat Pendek Berdasarkan Urutan Turunnya Wahyu. Bandung: Pustaka Hidayah, 1997.

------. Wawasan Al-Qur'an Tafsir Maudlui Atas Pelbagai Persoalan Umat, cet. X Bandung: Mizan, 2000.

Subhan, Arief. "Menyatukan Kembali Al-Qur'an dan Ummat, Menguak Pemikiran M. Quraish Shihab", dalam Jurnal Ilmu dan Kebudayaan Ulumul Qur'an, No. 5, Vol. IV Th. (1993).

Sumaryono, E. Hermeneutik Sebuah Metode Filsafat. Yogyakarta: Kanisius, 1999. 